\title{
Dual use Technology from Prehistoric Era to Modern Age: Utilization of Crossbow as a Lethal Weapon and an Agricultural Cum Research Device
}

\author{
Pradhuman Singh, Pierre Memheld, Maj. Arthur Cooke, Neeraj Anand
}

\begin{abstract}
Designed by the Vedic God Shiva, the crossbow has gone beyond mythical lore and became a tool of strategic warfare in helping decimate knights, paladins and armored cavalry by arbalests or men who shoot crossbows. This ancient design has stood the test of time and has still found favor with not only action cinema, but also the hunting community and the special forces across the world. It is interesting to note that the Far eastern as well as Nordic texts term it as a favorite tool of dragon slayers, it had found major applications in hunting whales, sharks and other edible marine harvests. Certain countries in the northern hemisphere issue crossbow licenses to farmers in ensuring crop protection from vermin as well as harvesting organic meat from any overpopulating species in a given area. Additionally, it has been extensively used to build rope based connectivity using hooks when a huge gap needs to be crossed. It has also evolved as a tool to track oceanic activities by pegging sensors on its tips to etch it on whales and thus gather crucial data as they navigate the sea. This evolution from an armor piercing weapon to a civilian application device goes to the next level when a crossbow bolt is used to gain atmospheric and aerial data without fear of gaseous exhaust or electro-magnetic fields of drones. The next progression may be of 'Cold launch missiles' that are nearly undetectable and may change the course of military technology in the times to come.
\end{abstract}

Index Terms: Aeronautics, Armor, Aviation, Avionics, Ballistics, Flight path, Force, Kinetic Energy, Penetration, Projectile, Trajectory.

\section{INTRODUCTION}

The crossbow is not only a weapon of combat but it is also a scientific instrument and a harvest cum fishing tool for farmers and fishermen across the world. Also, for an occasional traveler navigating unchartered territories, the crossbow serves as line launcher device for connectivity between two non-connected spaces. Today, it has also emerged as an extreme target sport and has been considerably popular in North America, Western Europe and Russian Federation. It has also been a tool of state policy for inciting Mongols who were the earliest users of this instrument. The

Revised Manuscript Received on July 5, 2019.

Pradhuman Singh, Indian, Asian \& Asia-Pacific Crossbow Shooting Champion 2019, International Federation of World Crossbow, PhD Scholar, University of Petroleum \& Energy Studies, Dehradun, India,

Captain Pierre Memheld (Retd), Executive Director, Global Risk Mgt, Faculty, Department of Business \& Economics, University of Strasbourg, Alsace, France.

Major Arthur Cooke, Corps of Infantry, Indian Army, Ministry of Defense, Kashmir Valley, India.

Dr Neeraj Anand, Head of Department, Department of Transportation, University of Petroleum \& Energy Studies, Dehradun, India. fears to the armored knights of Europe by Vikings and

startling fact is, that this technology has survived ancient, medieval and modern age and finds its utility in the present times [1]. This research paper aims to explore the origins, the present and the future of this device and technology.

\section{MOTIVATION FOR RESEARCH}

The key motivation for research is to explore this unique instrument from three different perspectives.

\subsection{The Military application perspective}

Crossbow was primarily designed for combat in penetrating armor and hence, still finds its application in battlefields across the world. Although it has been focused on special operations, it has brought desirable results in achieving military objectives in various applications ranging from counter insurgency to urban warfare and anti-terrorist campaigns.

\subsection{The Researcher perspective}

It has been widely used as a scientific tool of research to fix sensors on large mammals and marine life that allows marine biologists and scientists to collect data from a wide geography as well as oceanic depths that would not be possible always with robotic underwater instruments. Also, in modern aviation, aeronautical and aerospace studies, it has been, by far, not only a signaling tool but also serves as a drone launch platform with data collection capabilities.

\subsection{The target sport perspective}

Shooting a crossbow for target shooting is a comparatively new phenomenon in South Asia. However, in the modern times, it has emerged as a target sport which takes archery to an altogether another level. It employs both spinal as well as lower and upper body strength and dexterity of a unique kind that is highly varying from a conventional rifle, pistol or shotgun shooter.

\subsection{The farmer cum hunter's perspective}

Crossbow fishing has been a preferred tool to obtain larger fishes that are harder to catch by conventional methods such as angling and netting. A larger version called Ballista [2] was used in the older days mounted on ships used for whaling. Also, in whichever regions of the world, hunting is legalized, crossbows are given administrative licenses to neutralize vermin such as wild boars, blue bulls and other animals not only for food but also protecting agriculture produce and the food chain,

\section{Published By:}

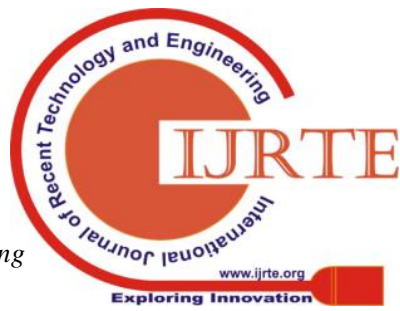


where excess population of certain animals would otherwise deprive region of vegetation needed for survival of other species.

\section{THEME WISE LITERATURE REVIEW}

\subsection{Technology}

Brodie \& Brodie (1973) deduce that the crossbow, if seen from the perspective of historical evidence, has clearly shaped history in greater ways than the nuclear bomb and compared its potency with that of a Hydrogen Bomb in mass usage [3].

Nishioka (1988) in his patent had clearly suggested that the trigger mechanism of a crossbow is far simpler, robust and time tested, thus making it more likely to find its usage in an unfriendly environment as compared to modern assault weapons that need greater care and upkeep [4].

Bednar (1997) in his patent earmarked the fact that a low resource military formation which would otherwise come under tremendous stress in the event of depletion of ammunition [5].

Shea, Davis \& Brown (2001) found that the ancient Javelin or a spear often had great penetrating power as compared to a modern rifle but had been discarded due to single usage and bulk. However, when a calibrated crossbow is used to send the projectile to a mid range target, it can have a similar lethal impact without the bulk and one time utility of a spear [6].

Rogers, Dowell, Choi \& Sathyavagiswaran (1990) study the various types of Crossbow injuries caused in conflict zones across the globe. The insight becomes more relevant where the crossbow has been ejected out by the shooter and often penetrated the armor or Kevlar protection of the target [7].

Foley, Palmer \& Soedel (1985) analyze the design and development of the crossbow as an instrument from the scientific perspective understanding the trigger mechanism and the precision brought out of the string, rail and prod system working in tandem [8].

\subsection{Implications}

Payne-Gallwey (1903) assessed the Crossbow in the light of events that took place in the medieval and modern times. With an insight into military and sporting applications and its evolution involving construction including variants such as Ballista and Catapult applied as siege weapons in the ancient times, crossbow has come a long way [9].

Lopez, Slessarev \& Lane (1969) examined the crucial role played by crossbow in the nautical revolution of the middle ages which not only involved establishing zip lines between ships and transfer of goods but also the whaling and other fishing applications that had a positive impact on the economies of on shore nation states [10].

Bliujiene (2002) delved into the major factors that were responsible for helping establish order post expansion in the Baltic states using the crossbow not just as a military weapon but also as a tool of state policy in helping suppress potential rebellion and dissent against the existing regimes [11].

Smith (2006) explores the usage of crossbow as a low cost tool for ensuring environmental balance and its subsequent categorization of hunting as both an act as well as a process of agriculture and pisciculture [12]. crossbow improves the chances of survival of a trooper in a

Payne-Gallwey (2007) took a relook at crossbow design and development with usage of compound technology and usage of modern rifle sights in military and sporting crossbow applications [13].

Wright (2005) dives deep into the expansion of rise of nomadic powers using crossbow as an infantry and cavalry weapon in the East as Mongols under Genghis Khan and in the West as Vikings under the leadership of Ragnar Lothbrok devised superior projectile weapon technology taking advantages of sedentary security of Chinese and European civilizations respectively and invading seemingly impossible empires in a go [14]. Bachrach throws the light on specialist crossbow designs that had specific applications and were designed for the nobility, knighthood and the immediate and next of the kin of the crowned king during the Reigns of John and Henry III of England. This was a time when technology transfer took place from France and eventually helping strengthen the English grip over its overseas territory [15].

Virk, Summerscales, Hall, Grove, \& Miles(2009) assessed the design, manufacture, mechanical testing and numerical modeling of an asymmetric composite crossbow limb in the light of greater usage of compounding technology in the modern applications of crossbow [16].

Pétrin (1992) derived the presence of advanced weapons of war in Indo-Proto-European cultures and military history focusing on Greek, Roman, and Byzantine empires with application of crossbow and related missile weapons [17].

Hsiao (2013) collated various studies and deduced that the original ancient Chinese design for a crossbow finds its applications in modern crossbows and can be applied to wide variety of usage for Canadian farmer and hunter using expertise in Mechanical engineering available to them [18].

Hsiao \& Yan (2012) studied the ancient Chinese state of Chu dynasty's repeating crossbow that was an innovative feature brought into combat science using the first concept of a magazine in a projectile. This was a structural advancement which was one of its kind developed in reconfigurable mechanisms as a result of weapon research [19]

Williams (2008) throws light on pre-Han Chinese bronze crossbow systems and triggers which owe their origin in Tibet and Mongolia region and had unparalleled manufacturing and finishing technology in the ancient world eventually finding its transfer all the way to Northern Europe thus causing a change of boundaries and empires in subsequent times [20].

Short \& King (1964) corroborate the design of a crossbow that is specific to hunting and agricultural usage and development of a broad-head or a dart which could be used for the immobilisation or neutralization of wild animals [21].

Landrus (2010) delves into the conceptualization of Leonardo da Vinci's giant crossbow design with wide ranging applications that are military, hunting, sporting and even scientific in nature. Incidentally, this is exactly what is being seen in the modern times come into light [22].

Nimavat (2016) traces the oldest mention of the crossbow in Shiva Purana as the name Pinaka which Shiva created to be used with His Trident as the rail. 
This was later transferred to Parshuram who used his battleaxe as the prod and wiped out a sizable chunk of warrior clan from the face of the earth, until broken by Lord Ram for marrying Sita [23].

\section{RESEARCH GAPS}

\subsection{Technology}

Basically, the crossbow system still relies upon the limbs, the riser, the strings, the prod, the rail and the trigger mechanism. Barring the introduction of cam pulleys with advances in metallurgy and composite materials, the basic design hasn't changed. The need for a new innovative and space age design is yet to be brought in conception.

\subsection{Implications}

From the literature review, it is clear that there is sizable chunk of information available on North America and ancient accomplishments in Europe and Asia are well documented for. However, in the modern times, how much has the crossbow impacted the turn of events in a military or a psycho-political scenario, is something not very visible at this stage.

\section{RESEARCH QUESTIONS}

5.1 What technological advances can be made in crossbow design to meet the demands of the future?

5.2 How far has crossbow continued to influence the socio-politico-military scenario the world over in the modern times?

\section{RESEARCh ObJECTIVES}

6.1 Identification of implementable designs for next generation of crossbow.

6.2 Identification of psychological impact of crossbow in civil and military roles.

\section{RESEARCH METHODOLOGY}

The research methodology is Qualitative in nature. It follows the deductive approach. Also, the underlying research philosophy is Positivism.

\section{RESEARCH DESIGN}

The research design is a hybrid design that involves 2 stages using qualitative tools.

\subsection{Historical Analysis}

This uses various historical events and incidents that have seem to have a bearing on both technological as well as overall impact of crossbows.

\subsection{Memheld scale [24]}

This scale uses 10 parameters to deduce the best viability of a product/technology/platform in a given situation. The 10 pointers for Memheld scale are as follows:-
8.2.1 Effectiveness
8.2.2 Efficiency
8.2.3 Precision
8.2.4 Repair ability
8.2.5 Cost advantage
8.2.6 Accuracy
8.2.7 Technology

\subsubsection{Adaptability \\ 8.2.9 Ease of training \\ 8.2.10 Simplicity}

\section{iX. Data Collection}

9.1 Method of Data collection for Historical Analysis

The following Sources were explored for historical data analysis

9.1.1 OSINT (Open Source Intelligence)

9.1.2. HUMINT (Human Intelligence)

9.2 Sources of Data for Memheld Scale

9.2.1 10 Crossbow shooters from across the world were handpicked using Slovin's formula. This can be understood as applied to a size of magnitude (n) for a population of the size (N) and an error margin (e), it may be derived as $n=N$ / $\left(1+\mathrm{Ne}^{2}\right) .10$ crossbow shooters gave a unanimous rating which included 10 finalists in $15 \mathrm{mtrs}, 18 \mathrm{mtrs}, 25 \mathrm{mtrs}, 40$ mtrs and pistol category at world championship qualifiers including serving military personnel, hunters and pure arbalest or crossbow shooters.

\section{Data tabulation}

Following are the data tabulation results.

\subsection{On the basis of design}

\begin{tabular}{|c|c|c|c|}
\hline Rating Pointers & $\begin{array}{c}\text { Recur } \\
\text { ve } \\
\text { Desig } \\
\mathrm{n}\end{array}$ & $\begin{array}{c}\text { Compound } \\
\text { Design }\end{array}$ & WIN/LOSS \\
\hline Effectiveness & 0 & 1 & Compound \\
\hline Efficiency & 0 & 1 & Compound \\
\hline Precision & 1 & 0 & Recurve \\
\hline Repair ability & 1 & 0 & Recurve \\
\hline Cost advantage & 1 & 0 & Recurve \\
\hline Accuracy & 1 & 0 & Recurve \\
\hline Technology & 0 & 1 & Compound \\
\hline Adaptability & 0.5 & 0.5 & NA \\
\hline Ease of training & 0.5 & 0.5 & NA \\
\hline Simplicity & 1 & 0 & Recurve \\
\hline SCORE & 6 & 4 & Recurve \\
\hline
\end{tabular}

Table 10.1 Recurve vs Compound (Source: author's research)

10.2 On the basis of manufacturer

\begin{tabular}{|c|c|c|c|c|c|c|c|}
\hline $\begin{array}{l}\text { Rating } \\
\text { Pointers }\end{array}$ & $\begin{array}{l}\text { Excali } \\
\text { bur }\end{array}$ & $\begin{array}{l}\text { Koda } \\
\text { bow }\end{array}$ & $\begin{array}{l}\text { Ten } \\
\text { point }\end{array}$ & $\begin{array}{l}\text { Barn } \\
\text { ett }\end{array}$ & $\begin{array}{l}\text { Scor } \\
\text { pyd }\end{array}$ & $\begin{array}{l}\text { Ravi } \\
\mathrm{n}\end{array}$ & $\begin{array}{l}\text { Mis } \\
\text { sio } \\
\text { n }\end{array}$ \\
\hline $\begin{array}{l}\text { Effectiven } \\
\text { ess }\end{array}$ & 7 & 7 & 7 & 1 & 4 & 4 & 2 \\
\hline Efficiency & 1 & 2 & 6 & 3 & 7 & 4 & 5 \\
\hline Precision & 6 & 7 & 5 & 1 & 2 & 3 & 4 \\
\hline $\begin{array}{l}\text { Repair } \\
\text { ability }\end{array}$ & 6 & 7 & 1 & 4 & 5 & 2 & 3 \\
\hline $\begin{array}{l}\text { Cost } \\
\text { advantage }\end{array}$ & 5 & 6 & 1 & 7 & 3 & 2 & 4 \\
\hline Accuracy & 6 & 7 & 5 & & & & 4 \\
\hline
\end{tabular}


Dual use Technology from Prehistoric Era to Modern Age: Utilization of Crossbow as a Lethal Weapon and an Agricultural Cum Research Device

\begin{tabular}{|l|c|c|c|c|c|r|r|}
$\begin{array}{l}\text { Technolo } \\
\text { gy }\end{array}$ & 6 & 5 & 7 & 1 & 2 & 4 & 3 \\
\hline $\begin{array}{l}\text { Adaptabili } \\
\text { ty }\end{array}$ & 6 & 7 & 5 & 1 & 2 & 3 & 4 \\
\hline $\begin{array}{l}\text { Ease of } \\
\text { training }\end{array}$ & 7 & 6 & 1 & 5 & 4 & 2 & 3 \\
\hline Simplicity & 6 & 7 & 1 & 3 & 4 & 2 & 5 \\
\hline SCORE & 56 & 61 & 39 & 7 & 35 & 29 & 3 \\
\hline
\end{tabular}

Table 10.2 Manufacturer (Source: author's research)

10.3 Active crossbow user units

\begin{tabular}{|l|c|c|}
\hline \multicolumn{1}{|c|}{ S.No } & Country & UNIT \\
\hline 1 & $\begin{array}{c}\text { People's Republic of } \\
\text { China }\end{array}$ & PLASOF \\
\hline 2 & Russian Federation & Spetsnaz \\
\hline 3 & United States & Delta Force \\
\hline 4 & United Kingdom & $\begin{array}{c}\text { Regiment de Dragoon } \\
\text { Parachutistes }\end{array}$ \\
\hline 5 & France & Marine Commandos \\
\hline 6 & India & 1st Raider Smyrni \\
\hline 7 & Greece & Ozel Kuvvetler \\
\hline 8 & Turkey & Specijalne Jedinice \\
\hline 9 & Serbia & ROKMC Recon \\
\hline 10 & South Korea & \\
\hline
\end{tabular}

Table 10.3 Active users (Source: author's research)

\section{Data Analysis}

\subsection{Recurve vs Compound}

From the table 10.1 it is evident that Recurve crossbow may be preferred where there is a need to operate in an environment where repair or maintenance support may not be available. Otherwise Compound works just fine provided servicing facility is available.

\subsection{Manufacturers}

From table 10.2 it is evident that Kodabow scored the highest followed by Excalibur and Ten Point. Except for Excalibur, which is Canada based, rest of the manufacturers are based in the United States. Barnett was originally based in the UK, but shifted to US after hunting laws were curtailed.

\subsection{Active users}

Referring table 10.3, there is a clear implication that all the P5 nations have their Special Forces and Special Operations team using the crossbow actively as a tool of war, low intensity conflict, counter terrorism and counter insurgency. This also includes military powers like India, Turkey and South Korea. Incidentally, crossbow wielding is not much visible in the public eye, but neither are the special force personnel.

\section{KEY FINDINGS}

12.1 Besides recurve and compound bow, even air crossbows are used. However, their use is avoided in active combat roles due to depletion of propellant gas.

12.2 Most crossbows can penetrate soft armor that can stop a rifle or a pistol bullet, but not always be able to penetrate armored vehicles. However, crossbow bolts with explosive heads can be utilized for several applications ranging from military to civilian usage including anti-material penetration. 12.3 In the Greek, Nordic and Oriental mythology, crossbow had been used as a favorite weapon of choice for Dragon slayers including Saint George. Incidentally, a larger version was actually being used to kill whales and larger sea animals including sharks and seals. In the recent times, it has been used to injure dragons in the popular TV series, Game of Thrones.

12.4 With hunting being legal in several parts of the world, a traditional hunter prefers a crossbow over a rifle due to its minimal sound and light signature and over a traditional bow due to its ability to store potential energy, helping the arbalest or crossbow shooter focus on the hunt. Also, it is considered more humane for the animal as it causes minimal pain and quicker death for the prey.

12.5 The epitome of crossbow application could be miniaturization of crossbow bolt into a mini probe/ drone/ or a nano-missile warhead with a cold-launch capability that could revolutionize civil and military aviation alike and prove game changing in peace as well as conflict scenarios. It could not only help researchers collect data with tremendous speed in real time but also help in bringing the costs down for several civilian, scientific, agricultural and military research applications.

12.6 Incidentally, in Syria, Iraq and Afghanistan, where suicide bombing has become a common phenomenon, a crossbow comes as a savior tool to neutralize such a threat since not only it is effective in Nuclear, Chemical and Biological warfare environment, it also neutralizes a suicide bomber without causing the explosive charge to go off, which would happen in case of a bullet. This has proven a major life saver by special forces operatives who have prevented major loss of lives in such conflict zones using a crossbow.

\section{KEY INFERENCES}

13.1 In spite of the active usage of firearms and automatic weapons, a conventional hunter and a special force operative would prefer a crossbow to engage in first strike.

13.2 'Simplicity is the highest form of sophistication', a saying by Steve Jobs perfectly summarizes as to why a 3 millennium old weapon technology is still finding active usage in modern warfare and hunting practices.

13.3 Scientific community majorly engaged in marine and aquatic research has not received much attention, however, the usage of the crossbow in this aspect is pretty much in and yet does not covered in media and press.

\section{RECOMMENDATIONS}

\subsection{Availability to security forces engaged in} non-conventional conflict zone

One major benefit that can be gained by making crossbow a weapon available to troops engaged in unconventional warfare is, saving on ammunition. The crossbow projectile, interchangeably referred to as Bolt or an Arrow, can be used several times without fail. This not only saves on overall cost but also allows scope for greater degree of survivability. 14.2 Research \& development into building hi-technology based micro-missile systems 
With innovation in drone and UAV (unmanned Aerial Vehicle) based technologies, a crossbow can be turned into a launch pad with each bolt a micro cruise missile that can be steered in real time through Satellite or radio wave transmission at short distances. This could revolutionize as an infantry weapon that can inflict casualties on adversary without causing collateral damage.

14.3 Low-cost, high quality manufacturing of crossbow components

The crossbow is a precision instrument and known for repeatable accuracy. This demands high- quality components that must be used to ensure uncompromising standards. Hence, a need to build an ancillary base that fulfills those standards at lower costs affordable to developing economies is a must.

\section{LIMITATIONS OF RESEARCH}

\subsection{Non-availability of classified data}

Ironically, most of the black ops information is considered top secret and there is very little of it available to the civilian researcher for analysis and data inference. Given this set of circumstances, only speculation based information or open source intelligence (OSINT) can be relied upon.

\subsection{Funding of full-fledged research}

There is very little initiative on research funding for innovation in crossbow technology being carried out beyond North America (which includes Canada and the United States) and Western Europe, where it is purely practiced in terms of a target sport. In Asia, due to heavy regulation, there is little that goes beyond Taiwan and People's Republic of China where research has been carried out on crossbow technology.

\subsection{Inability to carry out in-depth technology analysis}

Scientific application of crossbows has always been there but very little of it that is shared amongst fellow researchers for helping build cooperation platforms. Similarly, in the military and hunting domain, individuals have modified technology for their personal use and may not share it for mass usage, hence, it is not made available.

\section{SCOPE OF FURTHER RESEARCH}

\subsection{Integration into a micro missile system}

Turning a crossbow bold/arrow/projectile into a micro missile is something which may involve usage of nano-technology and cutting edge aviation research to build a guided missile system that is 50 times smaller than a conventional anti-tank/anti-material shoulder fired system and yet, extremely effective since the light and the sound originated at the launch source is minimal and yet the impact can be decisive.

16.2 Building cost-effective systems

Majority of the high quality crossbow systems are being manufactured in the United States and Canada. However, they still turn out to be expensive for an average crossbow user or arbalest. While there are manufacturing bases in China and Taiwan which may deliver a product at lesser cost, but the quality is not up to the minimal requisite standards required for a target or a hunting exercise.

16.3 Design and development of semi-automatic platforms Another challenge faced by the crossbow user is the ability to create effective loading mechanisms which can be done without losing time and force in the stroke. While air bows that use gas powered propelling mechanism are good, there is a need for better mechanism that does not depend on filling the gas tank in order to fire the bolt.

\section{CONCLUSION}

From the above study, it is pretty much clear that the crossbow shall continue to be the weapon of choice for a sizable chunk of Special force operatives, specialized hunters and target shooters across the world. It is amazing to note that this weapon has survived the test of time and continues to rely on the sheer force of the elasticity of composite elements and yet proves effective at accomplishing medium range targets and improvement in projectiles without ballistic propulsion. Needless to say, in an environment replete with low intensity conflicts and insurgency at various levels, it can prove an indispensible tool for managing proxy wars without compromising on civilian casualties and collateral damage.

\section{ACKNOWLEDGEMENTS}

1. Shidoshi Anil Kaushik Chairperson International Federation of World Crossbow.

2. Commander (Retd) Charles 'Chuck' Matasic. US Navy. Managing Director, Kodabow Inc.

3. Jeff Baker, CMO, U.S. Sales, Excalibur Crossbow Canada Inc.

\section{REFERENCES}

1. Peers, C. J. (1996), Imperial Chinese Armies (2): 590-1260AD, Osprey

2. Hart, V. G., \& Lewis, M. J. T. (2010). The Hatra ballista: a secret weapon of the past? Journal of Engineering Mathematics, 67(3), 261-273.

3. Brodie, B., \& Brodie, F. M. (1973). From Crossbow to H-bomb (No. 161). Indiana University Press.

4. Nishioka, J. Z. (1988). U.S. Patent No. 4,766,874. Washington, DC: U.S. Patent and Trademark Office.

5. Bednar, W. J. (1997). U.S. Patent No. 5,649,520. Washington, DC: U.S Patent and Trademark Office.

6. Shea, J., Davis, Z., \& Brown, K. (2001). Experimental tests of Middle Palaeolithic spear points using a calibrated crossbow. Journal of Archaeological Science, 28(8), 807-816.

7. Rogers, C., Dowell, S., Choi, J. H., \& Sathyavagiswaran, L. (1990) Crossbow injuries. Journal of Forensic Science, 35(4), 886-890.

8. Foley, V., Palmer, G., \& Soedel, W. (1985). The crossbow. Scientific American, 252(1), 104-111.

9. Payne-Gallwey, R. (1903). The Crossbow, Mediæval and Modern, Military and Sporting: Its Construction, History and Management, with a Treatise on the Balista and Catapult of the Ancients. Longmans, Green and Company.

10. Lopez, R. S., Slessarev, V., \& Lane, F. C. (1969). The crossbow in the nautical revolution of the middle ages. Explorations in Economic History, 7(1), 161.

11. Bliujienè, A. U. D. R. O. N. E். (2002). The main stylistic features of the Baltic crossbow brooches in the Migration period. Archaeologia Baltica.-Vilnius, 5, 145-161.

12. Smith, W. H. (2006). Crossbow Hunting. Stackpole Books.

13. Payne-Gallwey, R. (2007). The crossbow: its military and sporting history, construction and use. Skyhorse Publishing Inc.

14. Wright, D. C. (2005). Nomadic power, sedentary security, and the crossbow. Acta Orientalia, 58(1), 15-31.

15. Bachrach, D. S. (2004). Crossbows for the king: the crossbow during the Reigns of John and Henry III of England. Technology and culture, 45(1), 102-119.

16. Virk, A. S., Summerscales, J., Hall, W., Grove, S. M., \& Miles, M. E. (2009). Design, manufacture, mechanical testing and numerical modelling of an asymmetric composite crossbow limb. Composites Part B: Engineering, 40(3), 249-257. 


\section{Dual use Technology from Prehistoric Era to Modern Age: Utilization of Crossbow as a Lethal Weapon and an Agricultural Cum Research Device}

17. Pétrin, N. (1992). Philological notes on the crossbow and related missile weapons. Greek, Roman, and Byzantine Studies, 33(3), 265-291.

18. Hsiao, K. H. (2013). Structural synthesis of ancient Chinese original crossbow. Transactions of the Canadian Society for Mechanical Engineering, 37(2), 259-271.

19. Hsiao, K. H., \& Yan, H. S. (2012). Structural synthesis of ancient chinese chu state repeating crossbow. In Advances in Reconfigurable Mechanisms and Robots I (pp. 749-758). Springer, London.

20. Williams, D. (2008). Mass-produced pre-Han Chinese bronze crossbow triggers: unparalleled manufacturing technology in the ancient world. Arms \& Armour, 5(2), 142-153.

21. Short, R. V., \& King, J. M. (1964). The design of a crossbow and dart for the immobilisation of wild animals. Vet. Rec, 76, 628-630.

22. Landrus, M. (2010). Leonardo da Vinci's giant crossbow. Springer Science \& Business Media.

23. Nimavat, S. (2016). Demytholization in Amish Tripathi's "Scion of Ikshvaku".

24. Memheld, P. (2015). Memheld Scale. University of Strasbourg.

\section{AUTHORS PROFILE}

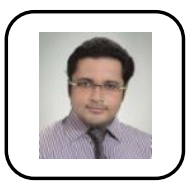

Pradhuman Singh A seasoned professional from the rea estate industry with grasp of Infrastructure, Research and Competitive Intelligence.

12 years of work experience in the real estate sector across Retail, Residential and Commercial markets with International and pan India exposure.

$\square$ Having worked in various capacities in the domains of Research, Sales, Marketing, Advertising, Public Relations, Leasing and handing over possession of properties.

$\square$ Conducted path breaking primary research in industry as well as academic domain eventually proving instrumental in strategy formulation, design and implementation.

$\square$ Sound understanding of quantitative as well as qualitative research methods including rare proficiency in $\mathrm{ACH}$ (Analysis of Competing Hypothesis) a qualitative research tool.

$\square$ Techno-savvy and hands on with systems and processes at operational as well as tactical levels.

$\square$ Author and Presenter of more than 18 research papers printed in various national and international journals across EU \& Asia.

$\square$ Speaks fluent Hindi, English and working French. Knowledge of basic Farsi and Arabic script.

$\square$ Team player and adaptable individual with a strong believer in inclusive growth and development.

$\square$ Gold Medalist -World Championship Qualifier 2019 in 40 mtrs, Asian Champion 2018 in 25 mtrs and Indian Champion 2019 in 40 and 18mtrs Crossbow Shooting.

$\square$ Avid reader, biker, keen writer, mountaineer, part time blogger, any time adventurer and once in a while cook.

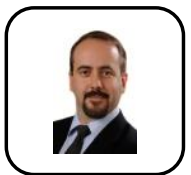

Capt (Retd) Pierre Memheld Competitive Intelligence / Compliance Risk Management speaker at Economics \& Management Faculty's Master of International Projects Management, University of Strasbourg. Executive Director at Global Risk Profile France. MBA from ESSEC Business School (Paris). Masters in Competitive Intelligence, Information Security and Technology Monitoring.

He has been conducting strategy consultancy missions in India, China, Japan, South Korea, Singapore, Russia, Germany, Italy, Morocco, Brazil and USA and the UAE/Qatar.

He has developed a core competency of industries analysis (aerospace, utilities, pharma, defense) in a market research environment either in Europe, Asia or Americas: I've worked on change management, technology development, merger \& acquisition, market entry and corporate strategy issues.

Specialties:

- Portfolios Analysis; Competitive Environment Assessment; Crisis Management; Communication Strategy;

- Information System; Statistical Analysis; Text Mining; Automatic Information Analysis; Databases; Softwares;

- Due Diligence; Compliance Management; Audit and Certification Corporate Strategy Definition;

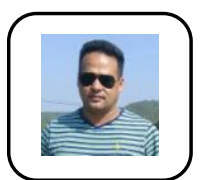

Maj. Arthur Cooke Major Arthur Augustus Stanley Mark Cooke is a serving officer in the Indian Army. He has commanded various formations in several active zones across the Indian Subcontinent. Major Cooke is a specialist in small arms as well as heavy calibre weaponry. He is credited with establishing a rifle \& pistol shooting range in close proximity to a regimental headquarters in North India. He is an active crossbow shooter and is presently stationed in a Counter Insurgency role in Kashmir valley.

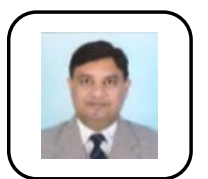

Dr Neeraj Anand Professor cum HOD Departement of Transportation, UPES, Dehradun.B.E. (Civil), Nagpur University, Nagpur.MBA, IMS, M.D.S. University, Ajmer.NET (Management) conducted by UGC.PGDRD(RuralDevelopment),IGNOU.Ph.D (Management), Sardar Patel University, Vallabhvidya Nagar (Guj.)

Area of Specialization; Supply Chain Management and Research Methodology.Other Areas: Operations Management, Marketing Management, Quantitative Techniques and Project Management. Author of several research papers and books. 